\title{
IAMJ
}

INTERNATIONAL

AYURVEDIC

MEDICAL JOURNAL

\section{CRITICS ON VIKALPA SAMPRAPTI IN UNDERSTANDING THE PATHOGENESIS WITH SPECIAL REFERENCE TO VICHARCHIKA}

\section{$\underline{\text { Shashirekha H.K }}{ }^{1}$, $\underline{\text { argale Sushant Sukumar }}^{2}$, Mandakini Prabha Singh ${ }^{3}$}

${ }^{1}$ HOD and Associate Professor, Department of Samhita and Sanskrit, IMS, Banaras Hindu University (BHU), Varanasi, UP, India

${ }^{2}$ Assistant Professor, Department of Swasthavritta and Yoga, Sri Dharmasthala Manjunatheshwara College of Ayurveda and Hospital, Hassan, Karnataka-573201, India

${ }^{3}$ Final Year Post Graduate Scholar, Department of Samhita and Siddhant Sri Dharmasthala Manjunatheshwara College of Ayurveda and Hospital, Hassan, Karnataka-573201, India

Corresponding Author: dr.shashirekha10@gmail.com

https://doi.org/10.46607/iamj1009082021

(Published Online: August 2021)

Open Access

(C) International Ayurvedic Medical Journal, India 2021

Article Received: 18/07//2021 - Peer Reviewed: 21/07/2021 - Accepted for Publication: 22/07/2021

\section{Check for updates}

\section{ABSTRACT}

Background: Vikalpa Samprapti is a unique concept that helps to estimate the fractional vitiation of Dosha and to understand the Tara and Tama Bhava of dosha involvement in disease. Evaluating the Tara and Tama of dosha vitiation is known as Amshamsha Kalpana. All Acharyas are unanimous about the involvement of Tridosha and four Dushya in the manifestation of Kushta. Despite this fact, there is variation in the Lakshana of each Kushta. There are multiple doshas involved in the condition, but a predominant dosha acts as a prime one in bringing about the symptoms. The causative factors responsible for any disease are identified by the knowledge of predominant dosha. Drugs and diets that possess opposite qualities to that of the predominant Dosha help to reverse the Samprapti and ultimately cure the disease. Objective: This study aims to evaluate the Dosha Vikalpa in Vicharchika and thereby finding a way to combat similar conditions. Materials and Methods: The current study was a cross-sectional observational study and was carried out in 100 subjects fulfilling the diagnostic and inclusion criteria of either gender of Vicharchika. These patients were categorised based on Lakshana of each Dosha, 
detailed clinical features of Vicharchika was recorded and the dosha involvement in each Lakshana were evaluated based on Dosha Lakshana explained in classics. Data obtained were analysed for statistical significance by adopting descriptive statistics. Results: The present study revealed that Vicharchika is predominantly Vataja; Vata Dosha Lakshana being considerably more observed in the highest 32 subjects (32\%). Conclusion: Vikalpa Samprapti provides knowledge of Tara Tama Bhava (degree of vitiation) of Dosha in Samsarga and Sannipataja Dushti. The current study concludes that the respective Doshas are responsible for the manifestation of the particular Lakshana in each Vyadhi.

Keywords: Vikalpa Samprapti, Dosha Vikalpa, Amshamsha Kalpana, Vicharchika, Tara Tama Bhava

\section{INTRODUCTION}

Dosha is the prime cause for the manifestation of disease. By assessing Lakshana exhibited in each vyadhi, the combination of dosha or its Dosha Vikalpa is traced out. There are multiple Dosha involved in the condition, but a single Dosha plays a pivotal role in bringing about the symptoms. ${ }^{[1]}$ The causative factors responsible for the progression of the disease are figured out by knowing the predominant Dosha involved in the Samprapti. Understanding the causative factors or nature of the predominance of Dosha helps in reversing the Samprapti. ${ }^{[2]}$ Every disease gets manifested with its cardinal symptoms which are obviously about that Dosha. Assessment of these symptoms helps to find the Dosha Vikalpa in disease. There are various factors responsible for the progression of pathogenesis. Depending upon the amount, duration and number of causative factors there are variations in the vitiation of any particular attribute of a Dosha which is well understood by the concept of Vikalpa Samprapti. ${ }^{[3]}$ Vitiation of Kapha Dosha leads to Kandu, Pidaka, Shyava Varna and Bahusrava in Vicharchika. Similarly, vitiation of Vata Dosha leads to Atikandu, Atiruja and Roukshya. Here, Kandu, being the feature of vitiated Kapha and Vata Dosha, needs to be analyzed properly to be specific in the selection of drugs. The proper understanding of Amshamsha Kalpana of Dosha through Vikalpa Samprapti helps in better planning of the treatment, not only in the case of vicharchika but in other diseases as well. Doshas are perceived as per the attrib- utes given to them. Vicharchika, as per Ayurveda Classics, varies in presentation depending upon the Amshamsha Kalpana of Dosha. Though Acharya Caraka has mentioned an innumerable number of Kushta depending upon Dosha Vikalpa, it is again classified as seven and eleven types respectively as MahaKushta and Kshudrakushta for Chikitsa Vishesha based on Dosha Amsa Amsa Vikalpa, Anubanda Dosha, Sthanavibhaga, Vedana, Samsthana, Varna and Prabhava. ${ }^{[4]}$ So, for a better understanding of disease in terms of Dosha Dushya involvement, the following study was carried out.

\section{Clinical trial registration number- (CTRI/2019/3/18311)}

\section{Materials and Methods}

Source of Data - Literary data were collected manually from classical textbooks of Ayurveda, textbooks of contemporary sciences, published articles from journals and authentic websites using keyword Vikalpa Samprapti, Vicharchika, Amshamsha Kalpana and Dosha Vikalpa.

\section{Applied Data}

Subjects of Vicharchika were selected from the OPD and IPD of Shri Dharamasthala Manjunatheshwara College of Ayurveda and Hospital, Hassan, Karanataka, India.

\section{Diagnostic Criteria}

Subjects were screened based on classical Lakshanas of Vicharchika mentioned in Table no. 1 
Table 1 (Diagnostic Criteria)

\begin{tabular}{|l|l|}
\hline S.N & Diagnostic Criteria $^{[\mathbf{5}]}$ \\
\hline $\mathbf{1}$ & Kandu (excoriation) \\
\hline $\mathbf{2}$ & Pidika (lesions) \\
\hline $\mathbf{3}$ & Shyaava (blackishness) \\
\hline $\mathbf{4}$ & Srava (discharge) \\
\hline $\mathbf{5}$ & Rukshata (dryness) \\
\hline $\mathbf{6}$ & Vedana (Pain) \\
\hline $\mathbf{7}$ & Raji (lichenification) \\
\hline
\end{tabular}

Assessment Criteria: The patients were assessed by using various subjective and objective parameters that were categorized based on the Dosha Lakshana explained in Kushta Chikitsa mentioned in Table no.2

Table 2: (Kushta Gata Dosha Lakshana) ${ }^{[6]}$

\begin{tabular}{|l|l|l|l|}
\hline S.N & Vata Dosha Lakshana & Pitta Dosha Lakshna & Kapaha Dosha Lakshana \\
\hline 1 & Parushayata & Swedana & Aswedana \\
\hline 2 & Nistoda & Vaivarnya & Syava \\
\hline 3 & Sphutana & Paridaha & Srava \\
\hline 4 & Lomaharsha & Ushanata & Klama \\
\hline 5 & Kharatwa & Raga & Gaurava \\
\hline 6 & Krushnatwa & Paka & Kandu \\
\hline 7 & Raji & Vedana & Pidika \\
\hline 8 & Kandu & Srava & - \\
\hline 9 & Rukshata & - & - \\
\hline
\end{tabular}

\section{Inclusion and Exclusion Criteria Inclusion Criteria-}

1. Diagnosed cases of Vicharchika based on given criteria.

2. Both gender between the age group 18-70 years.

3. Patients who are ready to give their consent.

Exclusion Criteria-

1. Patient other than Vicharchika. Patients suffering from other systemic diseases or suffering from any chronic disease like Diabetic Mellitus, HIV or HBsAg positive, pregnant women.

2. Patient those who are taking any immune suppressant medications.

3. Subjects who are not willing to participate

Study Design: Conceptual Cross-Sectional Observational Study

Enrollment of Subjects: A total of 150 subjects were screened for this trial. Among them, 100 subjects were included based on inclusion criteria.
Statistical Analysis: Data were analyzed using IBM SPSS statistics 23.0. Obtained data were analysed for statistical significance by adopting descriptive statistics.

Ethical Consideration: Ethical clearance was obtained from the ethical committee of the institute and the trial was registered under the clinical trial registry - India (CTRI/2019/3/18311)

Written consent was taken from each subject willing to participate in the study before the initiation of the study.

\section{Results:}

A total of 150 subjects were assessed for the eligibility criteria out of which 50 subjects were excluded and 100 subjects fulfilling the inclusion criteria were included in the study. Kushta Gata Dosha Lakshana mentioned in Charaka Samhita were taken as assessment criteria and all 100 subjects were taken for assessment of dosha lakshana. 
Table 3: Observation on Vata Dosha Lakshana $(\mathrm{N}=100)$

\begin{tabular}{|l|l|l|l|}
\hline Lakshana & Frequency & Percentage \\
\hline Parushyata (hardness) & Present & 49 & 49.0 \\
\cline { 2 - 4 } & Absent & 51 & 51.0 \\
\hline Nistoda (pricking pain) & Present & 7 & 7.0 \\
\cline { 2 - 4 } & Absent & 93 & 93.0 \\
\hline Sphutana (Cracking) & Present & 24 & 24.0 \\
\hline Lomaharsha (Horripulation) & Absent & 76 & 76.0 \\
\hline \multirow{2}{*}{ Kharatwa (Roughness) } & Present & 0 & 0.0 \\
\hline Krushnatwa (Blackishness) & Absent & 100 & 100.0 \\
\hline Rajyo (lichenification) & Present & 25 & 25.0 \\
\hline Kandu (Excoriation) & Absent & 75 & 75.0 \\
\hline Rukshata (dryness) & Present & 47 & 47.0 \\
\hline & Absent & 53 & 53.0 \\
\hline & Present & 22 & 22.0 \\
\hline & Absent & 78 & 78.0 \\
\hline & Present & 64 & 64.0 \\
\hline & Absent & 36 & 36.0 \\
\hline
\end{tabular}

Among 100 subjects, 49\% subjects were observed having Parushyata followed by Nistoda which was observed in 7\% subjects, Sphutana was observed in $24 \%$ of subjects, Lomaharsha was not at all observed, Kharatwa was observed in $25 \%$ subjects, Khrushnata was observed in $47 \%$ of subjects, Raji was observed in $22 \%$ of subjects, Kandu was observed in $64 \%$ of subjects and Rukshata was observed in $73 \%$ of subjects

Table 4: Observation on Pitta Dosha Lakshna $(\mathrm{N}=100)$

\begin{tabular}{|l|l|l|l|}
\hline Lakshana & Frequency & Percentage \\
\hline Swedana (profuse sweating) & Present & 24 & 24.0 \\
\hline Vaivarnya (discoloration) & Absent & 76 & 76.0 \\
\hline Paridaha (burning sensation) & Present & 16 & 16.0 \\
\hline Ushanata (increased temperature) & Absent & 84 & 84.0 \\
\hline \multirow{2}{*}{ Raga (Erythematous) } & Present & 32 & 32.0 \\
\hline Paka (suppuration) & Absent & 68 & 68.0 \\
\hline \multirow{2}{*}{ Vedana (pain) } & Present & 18 & 18.0 \\
\hline Srava (thin discharge) & Absent & 82 & 82.0 \\
\hline & Present & 13 & 13.0 \\
\hline & Absent & 83 & 83.0 \\
\hline & Present & 17 & 17.0 \\
\hline & Absent & 83 & 83.0 \\
\hline & Present & 4 & 4.0 \\
\hline & Absent & 96 & 96.0 \\
\hline
\end{tabular}


Among 100 subjects, Swedana was observed in 24\% of subjects, Vaivarnya was observed in $16 \%$ of subjects, Paridaha was observed in $32 \%$ of subjects, Ushnatawas observed in $18 \%$ of subjects, Raga was observed in $13 \%$ of subjects, Paka was observed in $17 \%$ of subjects, Vedana was observed in $4 \%$ of subjects and Srava was observed in $31 \%$ of subjects.

Table 5: Observation on Kapha Dosha Lakshana $(\mathrm{N}=100)$

\begin{tabular}{|c|c|c|c|}
\hline \multirow{3}{*}{$\begin{array}{l}\text { Lakshana } \\
\text { Aswedana (loss of sweating) }\end{array}$} & \multicolumn{2}{|c|}{ Frequency } & \multirow{2}{*}{$\begin{array}{l}\text { Percentage } \\
12.0\end{array}$} \\
\hline & Present & 12 & \\
\hline & Absent & 88 & 88.0 \\
\hline \multirow{2}{*}{$\begin{array}{l}\text { Shyava } \\
\text { (blackness) }\end{array}$} & Present & 27 & 27.0 \\
\hline & Absent & 73 & 73.0 \\
\hline \multirow[t]{2}{*}{ Srava (serous discharge) } & Present & 30 & 30.0 \\
\hline & Absent & 70 & 70.0 \\
\hline \multirow[t]{2}{*}{ Klama (drowsiness) } & Present & 14 & 14.0 \\
\hline & Absent & 86 & 86.0 \\
\hline \multirow[t]{2}{*}{ Gaurava (heaviness) } & Present & 17 & 17.0 \\
\hline & Absent & 83 & 83.0 \\
\hline \multirow[t]{2}{*}{ Kandu (itching) } & Present & 32 & 32.0 \\
\hline & Absent & 69 & 69.0 \\
\hline \multirow[t]{2}{*}{ Pidika (lesions) } & Present & 82 & 82.0 \\
\hline & Absent & 18 & 18.0 \\
\hline
\end{tabular}

Among 100 subjects, Aswedana was observed in 12\% of subjects, Syavata was observed in $27 \%$ of subjects, Srava was observed in $30 \%$ of subjects, Klama was observed in $14 \%$ of subjects, Gauravata was ob- served in $17 \%$ of subjects, Kandu was observed in $32 \%$ of subjects and Pidika were observed in $82 \%$ of subjects.

Table 5 (i): Dosha Vikalpa $(\mathrm{N}=100)$

\begin{tabular}{|l|l|l|l|}
\hline Dosha & VATAJA & PITTAJA & KAPHAJA \\
\hline Vata & $32(48 \%)$ & $0(0 \%)$ & $0(0 \%)$ \\
\hline Pitta & $0(0 \%)$ & $1(1 \%)$ & $0(0 \%)$ \\
\hline Kapha & $0(0 \%)$ & $0(0 \%)$ & $9(9 \%)$ \\
\hline Total & $32(32 \%)$ & $1(1 \%)$ & $9(9 \%)$ \\
\hline
\end{tabular}

Table 5 (ii): Dosha Vikalpa $(N=100)$

\begin{tabular}{|l|l|l|l|l|}
\hline$V P$ & $P K$ & $K V$ & $K P V$ & total \\
\hline $9(9 \%)$ & $0(0 \%)$ & $20(20 \%)$ & $5(5 \%)$ & 66 \\
\hline $1(1 \%)$ & $1(1 \%)$ & $0(0 \%)$ & $1(1 \%)$ & 4 \\
\hline $0(0 \%)$ & $11(11 \%)$ & $6(6 \%)$ & $4(4 \%)$ & 30 \\
\hline $10(10)$ & $12(12 \%)$ & $26(26 \%)$ & $10(10 \%)$ & 100 \\
\hline
\end{tabular}

Among $66 \%$, the majority of the subjects (48.4\%) were observed Swatantra Vata Lakshana followed by $13.6 \%$ being Vata in association with Pitta. Similarly, $30.3 \%$ had Vata in association with Kapha and 7.5\% had Vata in association with Tridosha. Among 4\% subjects of Pitta Dosha Pradhana Lakshana, 1\% subjects were observed Swatanatra Pitta Dosha Lakshana, $1 \%$ subject had Pitta in association with Vata, 
$1 \%$ subject's had Pitta in association with Kapha and $1 \%$ subject had Pitta in association with Tridosha. Among 30\% subjects of Kapha Dosha Pradhana Lakshana, 30\% subjects were observed with Swatantra Kapha Dosha Lakshana followed by $36.6 \%$ subjects who had Kapha in association with Pitta. Similarly, 20\% of subjects had Kapha in association with Vata Dosha and $13.3 \%$ of subject's had Kapha in association with Tridosha a shown in table no. 6 (I, II)

\section{DISCUSSION}

Dosha - Before outlining the treatment for the disease, the physician should examine the patient as well as the disease completely. The complete knowledge of vitiated Dosha, causative factors, signs and symptoms are necessary for diagnosing and treating the condition. ${ }^{[7]}$ Knowledge of involved Dosha and their state in pathogenesis is sufficient to manage the condition and provides definite results. Each dosha has its cardinal feature and functions in both Prakruta and Vaikruta states. In the present study, predominant Dosha Lakshana in the Samprapti of Vicharchika were evaluated. ${ }^{[8]}$

In all conditions whether the disease is known or unknown the physician should examine the patient and keenly observe the cardinal feature present in that disease to conclude the Dosha involvement. For example, if there is the presence of cardinal symptoms like Sramsa, Bhramsa, Vyaas, Sangha, Bheda, Saada, Harsha, Tarsha, Kampa, Varta, Chaala, Toda, Vyatha, Chesta, it is concluded that there is the involvement of vata. Similarly, increased Vaikruta Guna of Vata Dosha are Rooksha, Sheeta, Laghu, Vaishdhata, Gati, Amurtwa, Anavasthita. Observing these Lakshanas, one can conclude that the disease is Vata predominant. Similar other two Doshic conditions are also understood. ${ }^{[9]}$

Vikalpa samprapti - Vikalpa Samprapti provides the understanding of fractional variation in qualities of Dosha involved in pathogenesis. For example- in Vata- Kaphaja Vyadhi, the qualities of Vata Dosha and Kapha Dosha are opposite to each other to contribute to the pathogenesis. The Rooksha Guna of
Vata and the Snigdha Guna of Kapha Dosha, if gets aggravated, leads to comparatively weak Samprapti. $^{[10]}$ So, in Vata- Kapha disease condition the contributing qualities are Sheeta Guna of Vata Dosha and Snighdha Guna of Kapha Dosha which makes the pathogenesis stronger as well as difficult to manage. When more than one dosha is combined in disease the degree of qualitative and quantitative vitiation of Dosha varies from one disease to another and Amshamsha Kalpana of Vikalpa Samprapti provides a clear picture of Tara and Tama Bhava (degree of vitiation) of Dosha in Samsarga and Sannipataja Dushti. ${ }^{[11]}$

This concept provides the knowledge of etiological factors responsible for the pathogenesis of a particular disease that is essential for the selection of appropriate therapies which are opposite to that of a particular disease as well as the etiological factors (i.e. Vyadhi- Hetu- Pratidwandi) as the attributes of Dosha resembles the etiological factors which vitiate the dosha. ${ }^{[12]}$

Selection of disease - The principle of Kushta Chikitsa states that the Dosha Vikalpa should be evaluated before the initiation of the treatment so that the Pradhana Dosha involved in Samprapti is treated initially followed by Apradhana Dosha. This understanding of diagnosing Kushta and its management is the evidence showing the importance of Dosha Vikalpa mentioned in the classics. ${ }^{[13]}$

Vicharchika is mentioned among the list of Kshudra Kushta, and there is variation in the opinion regarding the involvement of dosha in pathogenesis of Vicharchika. The concept of manifestation of Kushta by Acharya Charaka shows that no Kushta is going to manifest by the single dosha and the concept of Sapta Dravya Samgraha ${ }^{[14]}$ gives the clear vision to understand all kinds of Kushta including Vicharchika.

Though Kushtha is a Tridoshaja Vaydhi, ${ }^{[15]}$ the present study was taken to further explore the extent of vitiation of any dosha so that we can plan the management after proper analysis of Dosha Lakshana and their predominance in the Samprapti. 
Vata pradhana vicharchika - In the present study, the majority of subjects $32(48.4 \%)$ were observed with Swatantra Vata Lakshana in Vicharchika followed by $9(13.6 \%)$ being vata in association with Pitta and similarly, 20 (30.3\%) had Vata in association with Kapha and 5 (7.5\%) had Vata in association with Tridosha. The subjects were observed with Swatantra Vata Pradhana Lakshana of Vicharchika, among them Vata Vaikrita Lakshana Rookshta, Kharata, Raji, Parushyata, and other symptoms were observed more than that of another dosha. Following this, in Vata-Pitta Pradhana Vicharchika, both Vata and Pitta Lakshanas were present; Vata Lakshana being slightly more. Similarly, in Vata-Kapaha Pradhana Vicharchika, both the sets of Lakahanas were present; Vata Dosha Lakshana being slightly more.

Pitta pradhana vicharchika - In the present study, among $4 \%$ subjects 1(25\%) subjects were observed with Swatantra Pitta Dosha Lakshana in Vicharchika, following this $1(25 \%)$ subject had Pitta in association with Vata, 1 (25\%) subject had Pitta in association with Kapha and 1 (25\%) subject had Pitta in association with Tridosha. The subjects observed with Swatantra Pitta Dosha Lakshana in Vicharchika were found to have more Pitta Vaikruta Lakshana like Daha, Raga, Paka, Srava and other Lakshana than other two Dosha. The subjects where pitta dosha was in association with both Vata and Kapha i.e., Vata-Piita Pradhana and Vata-Kapha Pradhana, combined Lakahanas were present; Pitta Dosha Lakshana being more than other two Doshas.

Kapha pradhana Vicharchika- In the present study, among 9 (30\%) subjects were observed with Swatantra Kapha Dosha Lakshana followed by 11(36.6\%) subjects who had Kapha in association with Pitta. Similarly, 6 (20\%) subjects had Kapha in association with Vata Dosha. The subjects observed with Swantantra Kapha Dosha Lakshana in Vicharchika were found to have more Kapha Dosha Lakshanas like Asweda, Srava, Pidika, Kandu, Gaurava, than the other two Dosha. The subjects where Kapha Dosha was in association with both Vata and Pitta Dosha i.e., Kapha- Vata Pradhana and Kapha-Pitta pradhana, combined Lakahanas were present; Kapha
Dosha Lakshana being more than the other two Doshas.

Tridosha vicharchika - In the present study, a total of 10 subjects were observed with Tridosha Lakshana in Vicharchika. Among these maxima in 5(7.5\%) subjects Vata Dosha Lakshana were observed more than the other two Dosha, in 1(25\%) Subject Pitta Dosha Lakshana was observed more than the other two Dosha, and in 6(20\%) subjects, Kapha Dosha Lakshana were observed more than other two Dosha. Among $100 \%$ subjects total of $10 \%$ subjects were observed with combined Lakshana of all three Dosha but Vata Lakshana were slightly more in maximum subjects of Tridosha Vicharchika.

\section{CONCLUSION}

The current study concludes that the respective Doshas are responsible for the manifestation of the particular Lakshana in each Vyadhi. Although there is variation in the opinion regarding the involvement of Dosha in Vicharchika, the present study revealed that it is predominantly Vataja; Vata Dosha Lakshana being considerably more than other Doshas. However, further exploration of the variation of this Dosha Lakshana as per the variation in the involvement of dushya can further deepen the understanding.

\section{REFERENCES}

1. Shastri Hari Sadashiva (Editor) of Ashtanga Hridaya Hemadri Commentary by Arunadatta Sutra Sthana, Chapter 12 Verse 32, 10th Ed. By, Chaukhambha Orientalia, Varanasi. (India); 2011.P.197

2. Shastri Hari Sadashiva (Editor) of Ashtanga Hridaya Hemadri Commentary by Arunadatta Nidana Sthana, Chapter 1 Verse 7, 10th Ed. By, Chaukhambha Orientalia, Varanasi. (India); 2011.P.194

3. Shastri Hari Sadashiva (Editor) of Ashtanga Hridaya Hemadri Commentary by Arunadatta Nidana Sthana, Chapter 1, Verse 5, 10th Ed. By, Chaukhambha Orientalia, Varanasi. (India); 2011.P.197

4. Shastri Hari Sadashiva (Editor) of Ashtanga Hridaya Hemadri Commentary by Arunadatta Nidana Sthana, Chapter 5 Verse 4, 10th Ed. By, Chaukhambha Orientalia, Varanasi. (India); 2011.P.216

5. Shastri Hari Sadashiva (Editor) of Ashtanga Hridaya Hemadri Commentary by Arunadatta Chikitsa Sthana, Chapter 7 Verse 26, 10th Ed. By, Chaukhambha Orientalia, Varanasi. (India); 2011.P.451 
6. Shastri Hari Sadashiva (Editor) of Ashtanga Hridaya Hemadri Commentary by Arunadatta Chikitsa Sthana, Chapter 7 Verse 34-36, 10th Ed. By, Chaukhambha Orientalia, Varanasi. (India); 2011.P.452

7. Das JR, Das HB, Mandal SK, Sharma SK. Role of Vikalpa Samprapti in disease in context to Prameha: A Review. IAMJ. 2015; 3:1. Accessed on $2^{\text {nd }}$ December 2019

8. Shastri Hari Sadashiva (Editor) of Ashtanga Hridaya Hemadri Commentary by Arunadatta Sutra Sthana, Chapter 20, Verse 12, 10th Ed. By, Chaukhambha Orientalia, Varanasi. (India); 2011.P.114

9. Shastri Hari Sadashiva (Editor) of Ashtanga Hridaya Hemadri Commentary by Arunadatta Sutra Sthana, Chapter 20, Verse 12, 10th Ed. By, Chaukhambha Orientalia, Varanasi. (India); 2011.P.114

10. Kuntal Ghosh, M.S. Baghel. Aclinical Study to Evaluate the Role of Doshik Predominance in the Management of Amlapitta: Ayu.2018; 38; 1-2 June 2017 Accessed On July 2019 http://www.ayujournal.org

11. https://easyayurveda.com/2018/06/20/amshamshakalpana/

12. Das Jr,Das Hb, Mandal Sk, Sharma Sk. Role Of Vikalpa Samprapti In Disease In Context To Prameha: A Review. Iamj.2015; 3:1 Accessed On $2^{\text {nd }}$ December 2019.

13. Shastri Hari Sadashiva (Editor) of Ashtanga Hridaya Hemadri Commentary by Arunadatta Chikitsa Sthana, Chapter 7, Verse 31,32, 10th Ed. By, Chaukhambha Orientalia, Varanasi. (India); 2011.P.451

14. Shastri Hari Sadashiva (Editor) of Ashtanga Hridaya Hemadri Commentary by Arunadatta Chikitsa Sthana, Chapter 7, Verse 9, 10, 10th Ed. By, Chaukhambha Orientalia, Varanasi. (India); 2011.P.450

15. Shastri Hari Sadashiva (Editor) of Ashtanga Hridaya Hemadri Commentary by Arunadatta Chikitsa Sthana, Chapter 7, Verse 31,32 10, 10th Ed. By, Chaukhambha Orientalia, Varanasi. (India); 2011.P.451.

\section{Source of Support: Nil \\ Conflict of Interest: None Declared}

How to cite this URL: Shashirekha H.K et al: Critics On Vikalpa Samprapti In Understanding The Pathogenesis With Special Reference To Vicharchika. International Ayurvedic Medical Journal \{online\} 2021 \{cited August 2021\} Available from: http://www.iamj.in/posts/images/upload/1659_1666.pdf 